\title{
Integrating Decomposers, Methane- Cycling Microbes and Ecosystem Carbon Fluxes Along a Peatland Successional Gradient in a Land Uplift Region
}

\author{
Heli Juottonen, ${ }^{1,2 *} \odot$ Mirkka Kieman, ${ }^{3}$ Hannu Fritze, ${ }^{4}$ Leena Hamberg, ${ }^{4} \odot$ \\ Anna M. Laine, ${ }^{3,5,6} \odot$ Päivi Merilä, ${ }^{7} \odot$ Krista Peltoniemi, ${ }^{4} \odot$ \\ Anuliina Putkinen, ${ }^{2,8,9} \odot$ and Eeva-Stiina Tuittila ${ }^{3,6} \odot$
}

\begin{abstract}
${ }^{1}$ Department of Biological and Environmental Science, University of Jyväskylä, P.O. Box 35, 40014 Jyväskylä, Finland; ${ }^{2}$ Department of Biosciences, General Microbiology, University of Helsinki, P.O. Box 56, 00014 Helsinki, Finland; ${ }^{3}$ Peatland Ecology Group, Department of Forest Sciences, University of Helsinki, P.O. Box 27, o0014 Helsinki, Finland; ${ }^{4}$ Natural Resources Institute Finland (Luke), P.O. Box 2, 00791 Helsinki, Finland; ${ }^{5}$ Present Address: Geological Survey of Finland, Neulaniementie 5, P.O. Box 1237, 70211 Kuopio, Finland; ${ }^{6}$ Present Address: School of Forest Sciences, University of Eastern Finland, P.O. Box 111, 80101 Joensuu, Finland; ${ }^{7}$ Natural Resources Institute Finland (Luke), Paavo Havaksen tie 3, 90570 Oulu, Finland; ${ }^{8}$ Environmental Soil Science, Department of Agriculture, University of Helsinki, P.O. Box 56, o0014 Helsinki, Finland; ${ }^{9}$ Institute of Atmospheric and Earth System Research (INAR)/ Forest Sciences, University of Helsinki, P.O. Box 56, o0014 Helsinki, Finland
\end{abstract}

\begin{abstract}
Peatlands are carbon dioxide $\left(\mathrm{CO}_{2}\right)$ sinks that, in parallel, release methane $\left(\mathrm{CH}_{4}\right)$. The peatland carbon $(\mathrm{C})$ balance depends on the interplay of decomposer and $\mathrm{CH}_{4}$-cycling microbes, vegetation, and environmental conditions. These interactions are susceptible to the changes that occur along a successional gradient from vascular plant-dominated systems to Sphagnum moss-dominated systems. Changes similar to this succession are predicted to occur from climate change. Here, we
\end{abstract}

Received 5 May 2021; accepted 16 September 2021; published online 19 October 2021

Supplementary Information: The online version contains supplementary material available at https://doi.org/10.1007/s10021-021-0071 3-w.

EST and HF conceived the study; EST, PM and AML performed field sampling and flux measurements; $\mathrm{MK}, \mathrm{HJ}, \mathrm{KP}$ and AP performed research in the lab; LH, MK, AML and HJ analyzed data; HJ, MK, HF, AML, LH and EST wrote the paper and all authors commented on it.

*Corresponding author; e-mail: heli.juottonen@alumni.helsinki.fi investigated how microbial and plant communities are interlinked with each other and with ecosystem $\mathrm{C}$ cycling along a successional gradient on a boreal land uplift coast. The gradient ranged from shoreline to meadows and fens, and further to bogs. Potential microbial activity (aerobic $\mathrm{CO}_{2}$ production; $\mathrm{CH}_{4}$ production and oxidation) and biomass were greatest in the early successional meadows, although their communities of aerobic decomposers (fungi, actinobacteria), methanogens, and methanotrophs did not differ from the older fens. Instead, the functional microbial communities shifted at the fen-bog transition concurrent with a sudden decrease in $\mathrm{C}$ fluxes. The successional patterns of decomposer versus $\mathrm{CH}_{4}$-cycling communities diverged at the bog stage, indicating strong but distinct microbial responses to Sphagnum dominance and acidity. We highlight young meadows as dynamic sites with the greatest microbial potential for $\mathrm{C}$ release. These hot spots of C turnover with dense sedge cover may represent a 
sensitive bottleneck in succession, which is necessary for eventual long-term peat accumulation. The distinctive microbes in bogs could serve as indicators of the $\mathrm{C}$ sink function in restoration measures that aim to stabilize the $\mathrm{C}$ in the peat.

Key words: ecosystem respiration; methane emission; fungi; actinobacteria; methanogens; methanotrophs; microbial biomass; microbial community; primary paludification; peatland development.

\section{HighLights}

- Early successional meadows were hot spots of microbial activity and carbon turnover.

- Microbial community shifted at the fen-bog transition with decreasing carbon flux.

- Microbes in bogs could be indicators for the carbon sink function of a peatland.

\section{INTRODUCTION}

About $30 \%$ of the global soil carbon (C) is stored in peatlands (Gorham 1991). Consequently, peatland ecosystems play a key role in controlling atmospheric carbon dioxide $\left(\mathrm{CO}_{2}\right)$ and methane $\left(\mathrm{CH}_{4}\right)$ concentrations (Yu 2012). They are unique habitats of largely water-logged organic soils, where changes in environmental conditions affect the interplay of primary producers and decomposers, which can turn the system into a C sink or source (for example, Laiho 2006). This interplay includes plants, fungi, bacteria, and $\mathrm{CH}_{4}$-producing archaea (methanogens) and $\mathrm{CH}_{4}$-oxidizing bacteria (MOB) especially, which are present under specific environmental conditions that are determined by moisture content and fertility level (Sottocornola and others 2009; Andersen and others 2011, 2013).

Climate change is likely to disrupt the complex interplay that determines the peatland $\mathrm{C}$ balance. In peatlands, the impacts of warming are expected to be coupled with drying due to increased evaporation (Roulet and others 1992; Monier and others 2013; Helbig and others 2020). Warming and drying are advantageous for the activity of most decomposers, thereby increasing the rates of mineralization (for example, Dieleman and others 2016). In addition, the community composition responds to environmental changes: vascular plants have an advantage over Sphagnum mosses in war- mer and drier conditions (Weltzin and others 2000; Breeuwer and others 2009; Dieleman and others 2015). The community response of fungi, actinobacteria, methanogens, and MOB to warming and drying appears to depend on peatland fertility (Jaatinen and others 2005; Peltoniemi and others 2009, 2015, 2016; Urbanová and Bárta 2016). Such community changes have been linked with alterations in several ecosystem functions, such as decreased C accumulation (Riutta and others 2007; Bragazza and others 2016; Laine and others 2019b) and increased decomposition of organic matter (Straková and others 2012). In general, drying appears to have a stronger impact on peatland communities and functions than warming (Peltoniemi and others 2016; Mäkiranta and others 2018; Laine and others 2019a, 2019b). Although the responses of individual communities (plants or microbes) to environmental changes have been studied to some extent, very few studies have linked the concurrent responses of multiple communities to ecosystem functions, such as $\mathrm{CO}_{2}$ and $\mathrm{CH}_{4}$ exchange (however, see Jassey and others 2013, 2018; Robroek and others 2015).

Northern peatlands are dynamic systems that typically have undergone succession from vasculardominated to Sphagnum moss-dominated systems during their development (for example, Bauer and others 2003). Similar rapid directional change has been reported as a response to altered hydrology as part of climate change (Gunnarsson and others 2002; Tahvanainen 2011). Concurrent with the plant community, the microbial communities also undergo successional change (Merilä and others 2006; Putkinen and others 2014). Peatland primary succession leads to changes in ecosystem functions, such as $\mathrm{CO}_{2}$ and $\mathrm{CH}_{4}$ exchange (Leppälä and others 2008, 201la, 201lb). Primary succession gradients make it possible to assess how tightly the different communities are linked and to predict changes in microbial composition based on the change in plant community structure. Peatland chronosequences at land uplift coasts (Glaser and others 2004; Tuittila and others 2013; Harris and others 2020; Laine and others 2021) offer excellent settings to study how the community changes are interlinked with ecosystem functions, as communities and functions can be studied under similar climatic and weather conditions.

The aim of this study was (1) to quantify how successional patterns in different functional groups (plants, fungi, actinobacteria, methanogens, MOB) are interlinked, and (2) to link the change in communities with the change in ecosystem functions $\left(\mathrm{CO}_{2}\right.$ production potential, $\mathrm{CH}_{4}$ production 
and oxidation potential, ecosystem respiration, $\mathrm{CH}_{4}$ emissions). We expected that as broad groups of aerobic litter decomposers, fungi and actinobacteria succession would closely follow that of vegetation because litter type appears to be a more important determinant of fungal and actinobacterial communities in boreal peatlands than hydrology (Peltoniemi and others 2009, 2012). Methanogens and MOB, on the other hand, were expected to follow the position of the water level (WL), which controls the aeration of the peat (Urbanová and others 2011; Yrjälä and others 2011), as well as the prevalence of sedges and Sphagnum mosses, which are substrate sources and habitats for $\mathrm{CH}_{4}$-cycling microbes, respectively (Ström and others 2003; Putkinen and others 2014).

\section{Materials AND Methods}

\section{Study Sites}

The study area is located on the Finnish coast of the Gulf of Bothnia $\left(64^{\circ} 45^{\prime} \mathrm{N}, 24^{\circ} 42^{\prime} \mathrm{E}\right)$, where new land is exposed from the sea due to post-glacial isostatic rising. On a $10-\mathrm{km}$ transect that extends from the shore inland, the sites comprise seven near natural peatlands (SJ0-SJ6), with successional stages that ranged from the onset of primary peat formation to a bog stage, which is considered as the final stage of succession (Table 1, Figure S1). The early stages (SJ0-SJ2) have a rather flat surface, while in the later stages (SJ3-SJ6) the peatland surface is patterned by microforms (dry raised hummocks, intermediate lawns, wet flarks with peat surface at or below water level (WL)). Typical microforms were lawns (Sphagnum covered) and flarks in SJ3 and SJ4, hummocks, lawns and flarks in SJ5, and shrubby hummocks, hummocks, and lawns in SJ6.

\section{Field Measurements}

From June to September 2007, $\mathrm{CH}_{4}$ and $\mathrm{CO}_{2}$ fluxes (ecosystem respiration, RE) were measured at weekly to biweekly intervals from 54 permanent sample plots $(0.56 \mathrm{~m} \times 0.56 \mathrm{~m})$ established to cover the site-specific variation in vegetation (Tables 1 and S1). Gas fluxes were measured with the static chamber method (see supplementary material for details). Water level and peat temperature at 5,10 , and $20 \mathrm{~cm}$ depths were measured close to each plot during the flux measurements. Plant species cover was inventoried from the same plots at the end of July 2007 (Table S1). Percentage cover of vascular and moss species was estimated visually using the scale $0.25,0.5,1,2,3-100 \%$.

\section{Peat Sampling and Physicochemical Analyses}

In August 2007, we collected two parallel sets of soil cores (one for microbiological and one for physicochemical analysis) with a box sampler $(8 \times 8 \times 100 \mathrm{~cm})$ or with a cylinder sampler $(4.5 \mathrm{~cm}$ diameter, $50 \mathrm{~cm}$ length) from each site along the transect. The cores were taken within $2 \mathrm{~m}$ of each gas flux sample plot from areas with similar vegetation to avoid disturbance on the plots. In addition to the sites with gas flux measurements (SJ0-SJ6), we took four cores from the sandy submerged littoral zone (SJml) near SJO to represent the soil before the land was exposed.

Table 1. Characteristics of Successional Stages Along the Peatland Gradient

\begin{tabular}{|c|c|c|c|c|c|}
\hline Site & $\begin{array}{l}\text { Successional } \\
\text { stage }\end{array}$ & $\begin{array}{l}\text { Terrestrial age } \\
(y)^{a}\end{array}$ & $\begin{array}{l}\text { Peat thickness } \\
(\mathrm{cm})^{\mathrm{a}}\end{array}$ & Typical vegetation & $\begin{array}{l}\text { Number of sample } \\
\text { plots }\end{array}$ \\
\hline SJml & $\begin{array}{l}\text { Under the sea } \\
\text { level }\end{array}$ & 0 & 0 & Phragmites & 4 \\
\hline SJO & Exposed shore & 70 & 0 & Grasses & 6 \\
\hline SJ 1 & $\begin{array}{l}\text { Epilobium mea- } \\
\text { dow }\end{array}$ & $100-180$ & $\leq 10$ & Grasses, sedges, brown mosses & 6 \\
\hline SJ2 & $\begin{array}{l}\text { Equisetum mea- } \\
\text { dow }\end{array}$ & $150-200$ & $\leq 10$ & Grasses, sedges, brown mosses & 6 \\
\hline SJ3 & Mesotrophic fen & $500-700$ & 50 & Sedges, Sphagnum sp. & 10 \\
\hline SJ4 & Oligotrophic fen & $1070 \pm 70$ & 75 & Sedges, shrubs, Sphagnum sp. & 9 \\
\hline SJ5 & $\begin{array}{l}\text { Fen-bog transi- } \\
\text { tion }\end{array}$ & $2520 \pm 50$ & 180 & $\begin{array}{l}\text { Sedges, shrubs, Sphagnum sp., } S \text {. } \\
\quad \text { fuscum }\end{array}$ & 8 \\
\hline SJ6 & Bog & $\sim 3000$ & $170-230$ & Shrubs, S. fuscum & 9 \\
\hline
\end{tabular}

${ }^{a}$ The values for terrestrial age and peat thickness are summarized from Merilä and others (2006) and Leppälä and others (2008). 
The sampling procedure covered the variation in moisture and vegetation typical of each site. The cores $(n=58)$, which reached depths of 30,45 , or $60 \mathrm{~cm}$, were cut at even intervals $(10,15$, or $20 \mathrm{~cm}$ ) resulting in three peat layers: uppermost, middle, and deepest layer (174 samples in total). The length of the interval depended on the peat depth and WL: longer sections were used for sites with deeper peat and WL. Varying the interval (that is, thickness of the three peat layers) allowed us to cover the peat above, around and below WL at each site despite their widely different peat depths (Table 1). Portions of the samples were used for measuring $\mathrm{pH}$ (soil:water $1: 5 \mathrm{v} / \mathrm{v}$ ) and to determine the potential rates of $\mathrm{CO}_{2}$ and $\mathrm{CH}_{4}$ production and $\mathrm{CH}_{4}$ oxidation. The remainder of the samples were frozen $\left(-20^{\circ} \mathrm{C}\right)$ for molecular and phospholipid fatty acid (PLFA) analyses. Parallel volumetric soil cores were used to determine bulk density, organic matter (OM; loss in weight on ignition, $\left.500{ }^{\circ} \mathrm{C}, 4 \mathrm{~h}\right)$, and total $\mathrm{C}$ and nitrogen $(\mathrm{N}$; LECO CHN-2000 analyzer). Results were calculated by volume based on the bulk density of the volumetric sample slices $\left(\mathrm{g} \mathrm{dm}^{-3}\right)$.

\section{Potential $\mathrm{CO}_{2}$ Production, $\mathrm{CH}_{4}$ Production, and $\mathrm{CH}_{4}$ Oxidation}

Potential activity measurements for the three peat layers (uppermost, middle, deepest) were carried out in 120 -ml flasks with $15 \mathrm{ml}$ of peat (see supplementary material for further details). The flasks for $\mathrm{CH}_{4}$ production contained $30 \mathrm{ml}$ of water and were flushed with nitrogen. The flasks for $\mathrm{CH}_{4}$ oxidation received $100 \mu \mathrm{l}$ of $\mathrm{CH}_{4}$ as substrate. The flasks were incubated at $15^{\circ} \mathrm{C}$ in the dark for 4 days $\left(\mathrm{CH}_{4}\right.$ production) or $1-2$ days $\left(\mathrm{CO}_{2}\right.$ production and $\mathrm{CH}_{4}$ oxidation). Gas concentrations were followed by gas chromatography as described in Perkiömäki and Fritze (2002; aerobic $\mathrm{CO}_{2}$ production), Jaatinen and others (2005; $\mathrm{CH}_{4}$ oxidation), and Merilä and others (2006; $\mathrm{CH}_{4}$ production). Production or oxidation rates were calculated from the slope of the linear regression of gas concentration change over time. The rates are given per sample volume (mg or $\mu \mathrm{g} \mathrm{dm}^{-3} \mathrm{~h}^{-1}$ ).

\section{Phospholipid Fatty Acid (PLFA) Analysis}

Fungal and bacterial biomass was analyzed by quantifying PLFAs from 1.5 to $4 \mathrm{~g}$ wet weight of peat or 4-6 g wet weight of mineral soil (Frostegård and others 1993; Jaatinen and others 2007). Relative fungal abundance (F-PLFA) was quantified from the amount of PLFA 18:2 $\omega 6$ (Frostegård and Bååth 1996; Kaiser and others 2010). The sum of twelve PLFAs (i15:0, a15:0, 15:0, i16:0, 16:1 $\omega 9$,

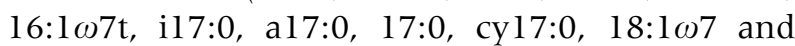
cy 19:0) was considered to represent bacterial abundance (B-PLFA) (Frostegård and Bååth 1996). PLFAs 10 Mel7 and 10Mel8 were considered to represent actinobacteria (Act-PLFA) (Kroppenstedt 1985). The quantity of the PLFAs was determined in relation to the sample volume $\left(\mu \mathrm{mol} \mathrm{dm}^{-3}\right)$ by calculating the results per dry weight $\left(\mu \mathrm{mol} \mathrm{g}^{-1}\right)$ and multiplying with the sample-specific bulk density $\left(\mathrm{g} \mathrm{dm}^{-3}\right)$.

\section{Molecular Analyses of Microbial Groups}

Total DNA was extracted from the soil with a Power Soil DNA extraction kit (MoBio Laboratories, Inc., Carlsbad, CA, USA). Fungi were amplified with primers ITS $1 F$ and ITS2 for the internal transcribed spacer region (Gardes and Bruns 1993). Actinobacterial primers were S-C-Act-0235-a-S-20 and S-C-Act-0878-a-A-19 for actinobacterial 16S ribosomal RNA gene (Stach and others 2003). Type II methanotrophs (tII-MOB) were detected with primers Al89f and A621r (Holmes and others 1995; Tuomivirta and others 2009) for methanotrophspecific pmoA gene for particulate methane monooxygenase. Methanogens were detected with the primers of Luton and others (2002) that amplify methanogen-specific morA gene for methylcoenzyme $M$ reductase. Fungal, actinobacterial, and type II MOB communities were analyzed by denaturing gradient gel electrophoresis (DGGE) and sequencing of DGGE bands. Methanogens were analyzed by terminal fragment length polymorphism (T-RFLP) and sequencing of clones. The details of PCR, DGGE, and T-RFLP are described in the supplementary material. The DGGE banding patterns of fungi, actinobacteria, and tII-MOB were compiled into presence-absence matrices. DGGE bands with divergent mobility were considered as operational taxonomic units (OTUs). For methanogens, T-RFs of different lengths were considered as OTUs and relative peak areas were used as relative abundances. The OTUs that appeared at least twice in a dataset were included in the community composition data. To determine taxonomic affiliations, we constructed phylogenetic trees of DGGE band sequences (fungi, actinobacteria, tII-MOB) and clone sequences (methanogens; see supplementary material for details). DNA sequences were submitted to the European Nucleotide Archive under accession numbers LN681001-LN681094 (fungi), LN681095-LN681133 (actinobacteria), 
LN681148-LN681172 (tII-MOB), and LR999478LR999518 and HG993108-HG993123 (methanogens).

\section{Statistical Analyses}

The effects of soil properties on potential microbial activities and biomass were investigated using generalized additive mixed models (GAMMs) in package mgcr with function gamm (Wood 2006) in R (v. 3.1.1, R Core Team 2014). Normal distribution was assumed but response variables were logtransformed when needed to achieve normality. All sample plots in SJO-SJ6 were included in the analyses $(n=54)$. Models were estimated separately for each soil layer. Because many of the variables that describe soil properties were strongly correlated (Table S2), only the most important (that is, $\mathrm{WL}, \mathrm{OM}$, and $\mathrm{pH}$ ) were included in the models. Water level, as the mean of the measurements up to the sampling date, was included in the model as a categorical variable with values 0 (the vertical middle point of a sample below the mean $\mathrm{WL}$ ) and 1 (the vertical middle point of a sample above the mean $\mathrm{WL}$ ). We considered this an acceptable estimation of the differences in the moisture conditions at a rather small spatial scale (Figure S2). Organic matter and $\mathrm{pH}$ were smoothed when the models were estimated. In addition to these fixed effect variables, site was included as a random factor in the models. Response curves were drawn based on GAMMs using mean values for the other explanatory variables rather than those of interest in the models.

Global non-metric multidimensional scaling (GNMDS) was performed for the vegetation and each microbial group to investigate changes in these communities along the successional gradient, using the vegan package (v. 2.3-0, Oksanen and others 2015) in R. The Bray-Curtis dissimilarity measure was used for vegetation (cover data), Raup-Crick for fungi, actinobacteria and tII-MOB (binary data), and Gower for methanogens (numeric data). Separate MetaMDS runs were performed 50 times to ensure the best possible solution (that is, to avoid local optima). The solution with the lowest stress value was chosen. Environmental variables were fitted using permutation tests. Species that occurred in at least in five samples were drawn to species ordination figures. The effect of successional stage and peat layer on microbial communities was tested with permutational analysis of variance (PERMANOVA) (Anderson 2001) with the function adonis2 in the vegan package. Procrustes analysis with the functions procrustes and protest in the vegan package based on the first four NMDS dimensions was used to compare the successional patterns of different functional groups (Peres-Neto and Jackson 2001; Lisboa and others 2014). The Procrustes analysis between vegetation and microbial groups only included the uppermost and middle layers to focus on the layers influenced by the surface vegetation. The analyses between microbial groups included all layers. The distance measures in PERMANOVA and Procrustes analysis were the same as in GNMDS. Finally, we used the Procrustes residuals to compare the strength of correlation among microbial groups along the peatland succession (Lisboa and others 2014). Differences between successional stages were determined with analysis of variance and Tukey's post hoc tests.

\section{RESUlTS}

\section{Vegetation, Soil Chemical Variables, Gas Fluxes and Microbial Biomass Along the Peatland Succession}

Along the successional gradient, total vegetation cover increased from $<20 \%$ in recently exposed shore SJ0 to nearly $150 \%$ in bog SJ6 (Figure la, Table S3). From the fen SJ3 onward, the increasing vegetation cover was due to the increase in shrubs (Figure 1b) and Sphagnum mosses (Figure 1c). Sedge cover was highest in the fen SJ3. Organic matter density tripled from meadow SJ2 to fen SJ3, indicating the start of peat accumulation (Figure lf). Although $\mathrm{OM}, \mathrm{C}$, and $\mathrm{N}$ densities were greatest in the fen sites SJ3 and SJ4, C:N increased throughout the gradient (SJ0-SJ6) (Figure lg). Acidity increased along the gradient from $\mathrm{pH} 6.1$ in SJ0 to 4.2. in SJ6 (Figure le). Water level was lowest in the bog SJ6 (Figure le).

Ecosystem respiration peaked in fen SJ3 (Figure ld). $\mathrm{CH}_{4}$ emissions showed rather similar levels in sites SJI-SJ5 and were lowest at the end points of the gradient (Figure ld). The greatest microbial activity potential, as indicated by the rates of aerobic $\mathrm{CO}_{2}$ and anaerobic $\mathrm{CH}_{4}$ production, was measured at the meadow sites, especially SJ2 (Figure lh). In contrast, potential $\mathrm{CH}_{4}$ oxidation increased from SJO to SJ2 and then remained at this elevated level along the whole gradient. Fungal, bacterial, and actinobacterial biomass peaked in the meadow sites and were greatest in SJ2. The ratio of fungi to bacteria $(\mathrm{F}: \mathrm{B})$ was greatest in the oldest sites SJ5 and SJ6 (Figure li). 


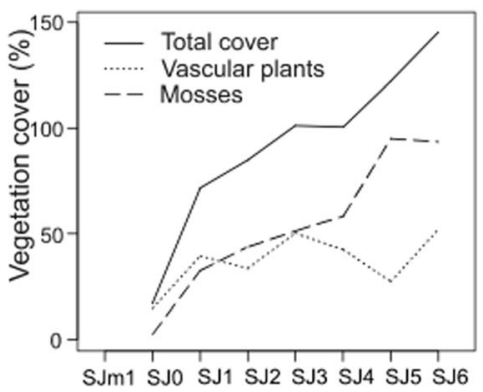

- d.

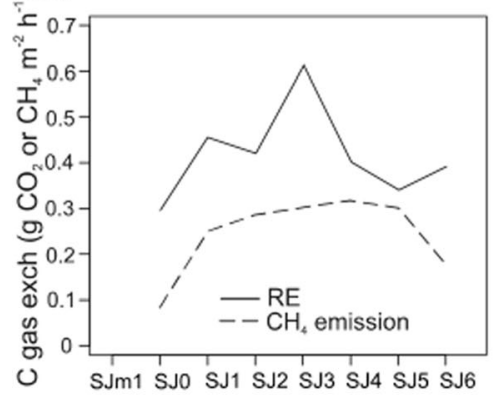

g.

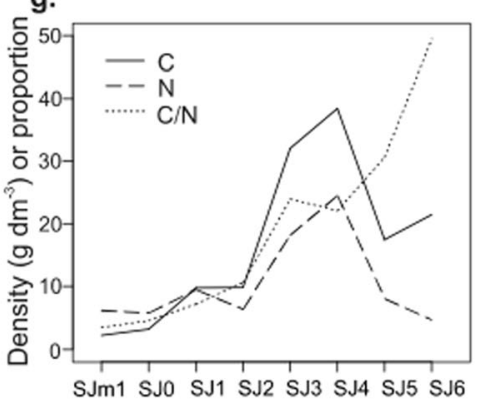

b.

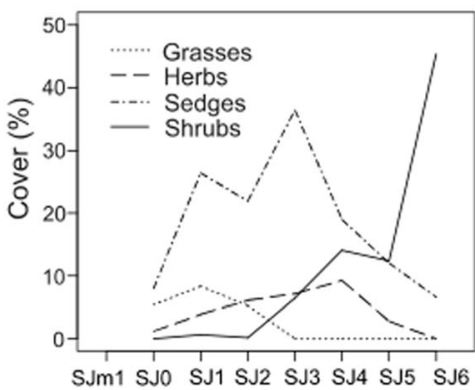

e.

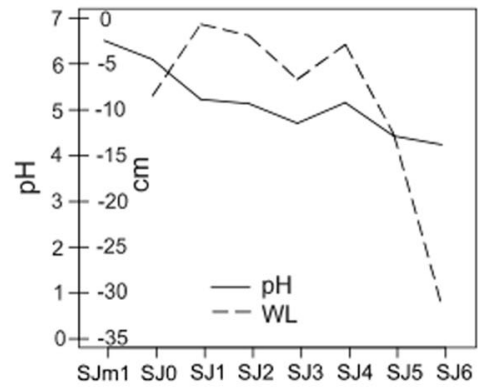

h.

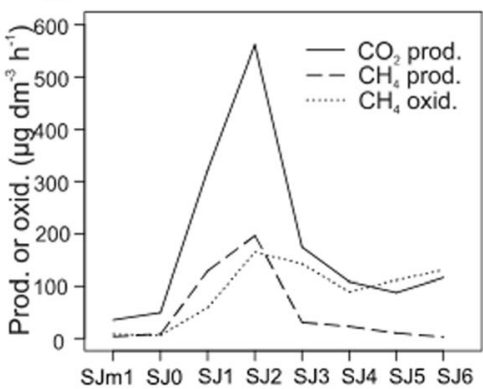

c.

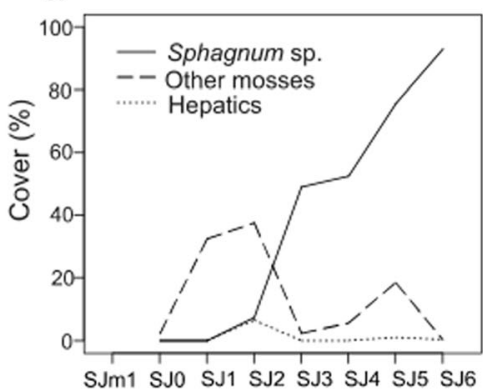

f.

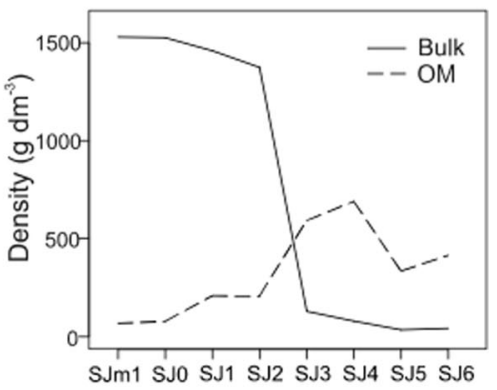

i.

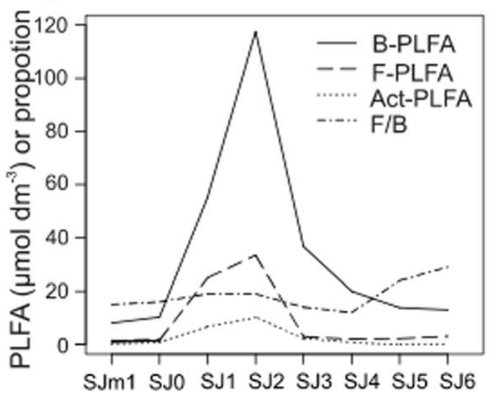

Figure 1. Variables describing peatland succession (SJ0-SJ6) with land uplift from the sea (SJml): a-c plant functional type cover, $\mathbf{d}$ ecosystem respiration (RE) and methane $\left(\mathrm{CH}_{4}\right)$ emissions, e-g water level (WL) and soil properties, $\mathbf{h}$ potential rates of carbon dioxide $\left(\mathrm{CO}_{2}\right)$ (aerobic) and $\mathrm{CH}_{4}$ production and $\mathrm{CH}_{4}$ oxidation, and i microbial biomass: B-PLFA, bacterial phospholipid fatty acids (PLFAs); F-PLFA, fungal PLFAs; Act-PLFA, actinobacterial PLFAs; F:B is the ratio of fungal to bacterial PLFAs. Values are site means including three peat layers (SJm1 $n=12 ; \mathrm{SJ} 0-\mathrm{SJ} 2 n=18$; SJ3 $n=30$; SJ4 $n=27$ : SJ5 $n=24$; SJ6 $n=27$ ). To fit the scale, $\mathrm{F}: \mathrm{B}$ and $\mathrm{CH}_{4}$ emissions are presented 100 times larger, organic matter $(\mathrm{OM})$ and nitrogen $(\mathrm{N}) 10$ times larger, and $\mathrm{CO}_{2}$ production 10 times smaller than the initial values.

\section{Within-Site Variation in Relation to Microform and Peat Layer}

To capture the pronounced vertical variation and horizontal patterning typical of boreal peatlands, our sampling strategy covered three peat layers and the different microforms in the stages where microforms were present. The young meadow sites SJ0-SJ2 showed no horizontal patterns of vegetation cover, C fluxes, soil properties, or microbial variables. These sites had a thin organic surface layer that covered the mineral soil (Table 1). Vertically, this layer showed the greatest $\mathrm{CO}_{2}$ and $\mathrm{CH}_{4}$ production and $\mathrm{CH}_{4}$ oxidation rates and microbial biomass at these sites (Table S4). In the older sites SJ3-SJ6 with thicker peat layer and microforms, the cover of Sphagnum mosses and shrubs was greater in drier microforms (lawns in SJ3 and SJ4, hummocks in SJ5 and SJ6) (Table S5). Microformrelated variation in $\mathrm{RE}$ was low, whereas $\mathrm{CH}_{4}$ emissions were generally greater in the moister microforms within the sites SJ3-SJ6. Potential $\mathrm{CO}_{2}$ production in the older sites did not vary with depth or microform. Potential $\mathrm{CH}_{4}$ production in SJ3-SJ6 was generally greater below WL and in the moister microforms (Tables $\mathrm{S} 4-\mathrm{S} 6$ ). $\mathrm{CH}_{4}$ oxidation rates were generally greater below the uppermost layer, especially in the drier microforms. Fungal 
biomass decreased with depth in SJ3-SJ6, whereas bacterial and actinobacterial biomass were mainly greatest in the middle layer (Table S6).

\section{Relationship of Microbial Activity Potentials to Soil Variables Based on Generalized Additive Mixed Models (GAMMs)}

Potential $\mathrm{CO}_{2}$ production increased with increasing OM density in all layers (Figure $2 \mathrm{a}-\mathrm{c}$ ). In the middle layer, $\mathrm{CO}_{2}$ production leveled at an $\mathrm{OM}$ density of about $70 \mathrm{~g} \mathrm{dm}^{-3}$ and greater (Figure $2 \mathrm{~b}$ ). The deepest layer showed greater $\mathrm{CO}_{2}$ production when the layer was above the WL
(Figure 2c). Similarly, potential $\mathrm{CH}_{4}$ production was affected by the position of the WL (Figure $2 \mathrm{~d}-$ f). In the surface layer, $\mathrm{CH}_{4}$ production increased with higher $\mathrm{pH}(>5)$ but only when the layer was below the WL (Figure 2d). In the middle layer, none of the selected soil properties explained the $\mathrm{CH}_{4}$ production rate, with the possible exception of WL $(p=0.059)$. In the deepest layer, only a weak link was observed between $\mathrm{CH}_{4}$ production and increasing OM density, but only if this layer was above the WL (Figure 2f). The response of potential $\mathrm{CH}_{4}$ oxidation depended on the peat layer. In the surface layer, $\mathrm{CH}_{4}$ oxidation increased with increasing $\mathrm{OM}$ density, especially under the $\mathrm{WL}$ and at $\mathrm{pH} 5$ (Figure $2 \mathrm{~g}$ ). In the middle layer, $\mathrm{CH}_{4}$

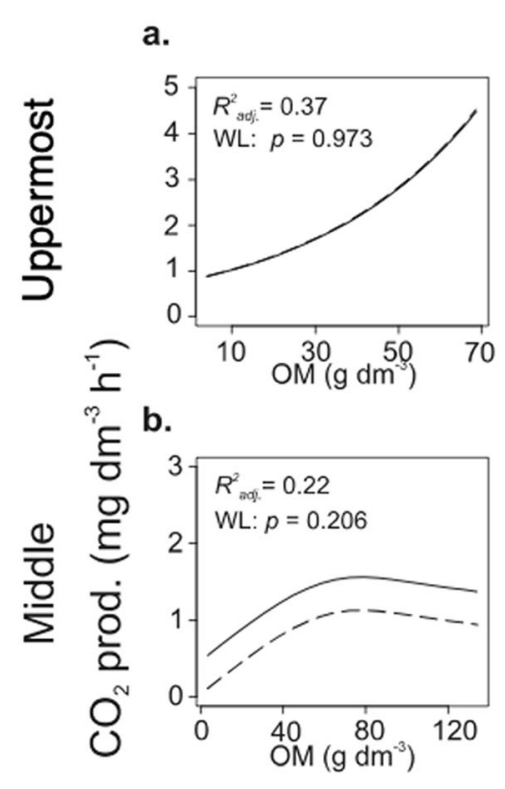

c.

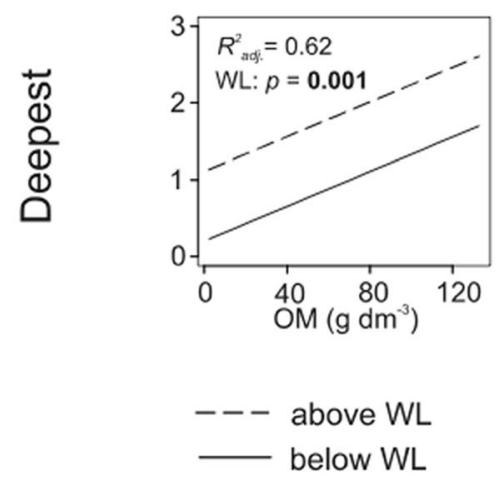

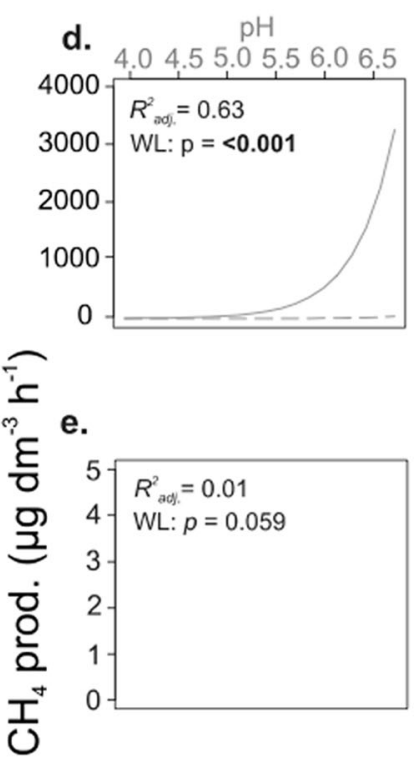

f.
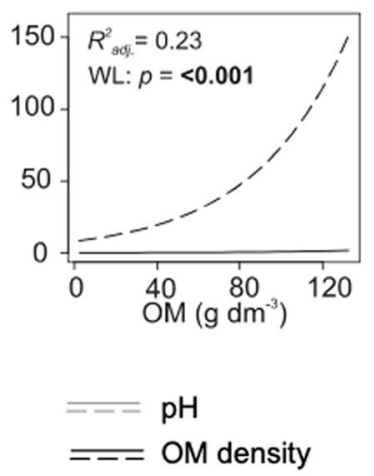
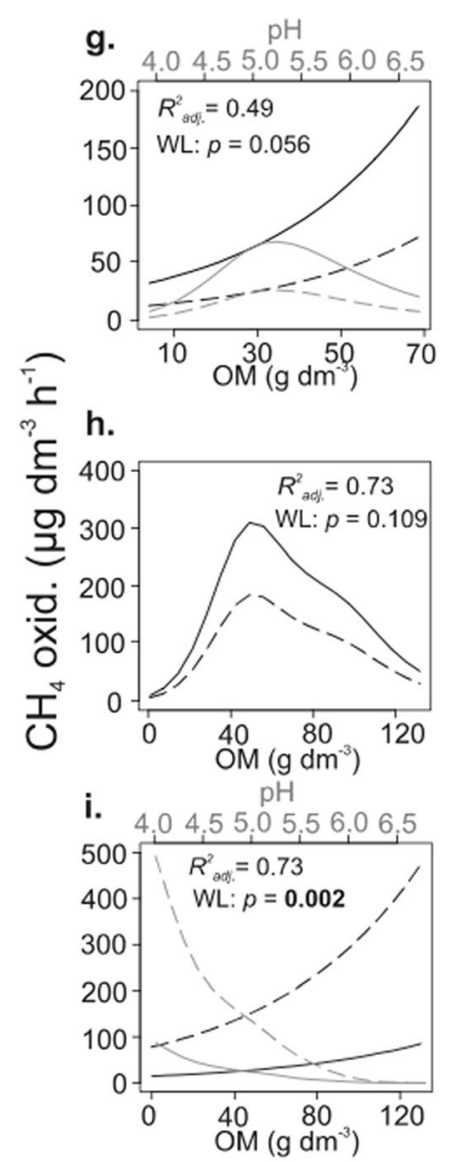

Figure 2. Effects of water level (WL), organic matter (OM) density, and $\mathrm{pH}$ on the microbial activity potentials (aerobic $\mathrm{CO}_{2}$ production, $\mathrm{CH}_{4}$ production, and oxidation) for three peat layers. Sites SJO-SJ6 were included in the model for each layer $(n=54)$. Response curves were drawn based on generalized additive mixed models (GAMMs) so that explanatory variables other than the presented variable were retained as their mean value. The effects of $\mathrm{OM}$ and $\mathrm{pH}$ are presented only when $p<0.05$. All effects of the WL categories (above, below) are shown ( $p$ values in bold when $p<0.05$ ). Empty subfigure e had no significant soil properties. In figures $\mathbf{d}-\mathbf{i}$ : black denotes OM density; gray denotes $\mathrm{pH}$. Note the different axis scales. $R_{\text {adj. }}^{2}$ adjusted $R^{2}$ value of the model. 
oxidation varied strongly with $\mathrm{OM}$ density and peaked at an OM density of about $50 \mathrm{~g} \mathrm{dm}^{-3}$ (Figure $2 \mathrm{~h}$ ). In the deepest layer, $\mathrm{CH}_{4}$ oxidation was accentuated, especially above the WL, by increasing acidity and OM (Figure 2i).

\section{Plant and Microbial Communities Along the Peatland Gradient}

Vegetation formed a clear gradient from SJ0 to SJ6 (Figure 3); from grass- to sedge-dominated communities, and finally to Sphagnum-dominated vegetation (including dwarf shrubs). Bulk density, $\mathrm{pH}$, C:N, and the cover of Sphagnum and shrubs showed the greatest correlation $(r \geq 0.74)$ with plant community change (Table S7). Overall microbial community structure based on PLFAs showed a similar, though less differentiated, successional gradient and separated the young meadows (SJI, SJ2), midsuccessional fens (SJ3, SJ4), and the oldest bog sites (SJ5, SJ6) from each other (Figure 4). At the level of microbial functional groups, successional stage explained a larger proportion of community variation than peat layer for all the groups (Table 2). The community structure of fungi, actinobacteria, and methanogens showed a common pattern where the late stages (SJ5, SJ6) were separated from the other stages, and the early (SJ0-SJ2) and mid-successional (SJ3, SJ4) stages were grouped together (Figure 5a-i, Figure S3). Methanotrophs were not detected in the youngest sites (SJ0, SJ1). The tII-MOB community in the oldest sites (SJ5,
SJ6) was separated from the younger sites, but tIIMOB also differed more clearly with peat layer than the other groups (Figure $5 \mathrm{j}-\mathrm{l}$ ). Changes in the fungal, actinobacterial, and tII-MOB communities correlated best with $\mathrm{C}: \mathrm{N}, \mathrm{pH}$ and the cover of Sphagnum and shrubs, and the methanogen communities with C, N, and OM density and Sphagnum cover (Table S8). We used Procrustes analysis, which superimposes two ordinations, to compare the successional patterns of vegetation and microbial functional groups. Fungal community showed the greatest correlation with vegetation composition, and actinobacteria the lowest (Table 2). When comparing the successional patterns of the different functional groups, the strongest correlations were seen between actinobacteria and fungi, and between actinobacteria and methanogens, and lowest between methanogens and tII-MOB (Table 2). Procrustes residuals showed a fairly uniform correlation of actinobacteria vs. fungi and methanogens vs. tII-MOB along the gradient (Figure 6). Procrustes residuals of actinobacteria and fungi with $\mathrm{CH}_{4}$-cycling microbes increased toward the bog sites, particularly the oldest site SJ6, indicating decreasing correlation of community patterns.

\section{Phylogenetic Affiliation of the Microbial Groups}

The majority of fungal sequences clustered with Ascomycota and Pezizomycotina, including genera Penicillium (SJ0), Articulospora (SJ0, SJl, SJ4), a.

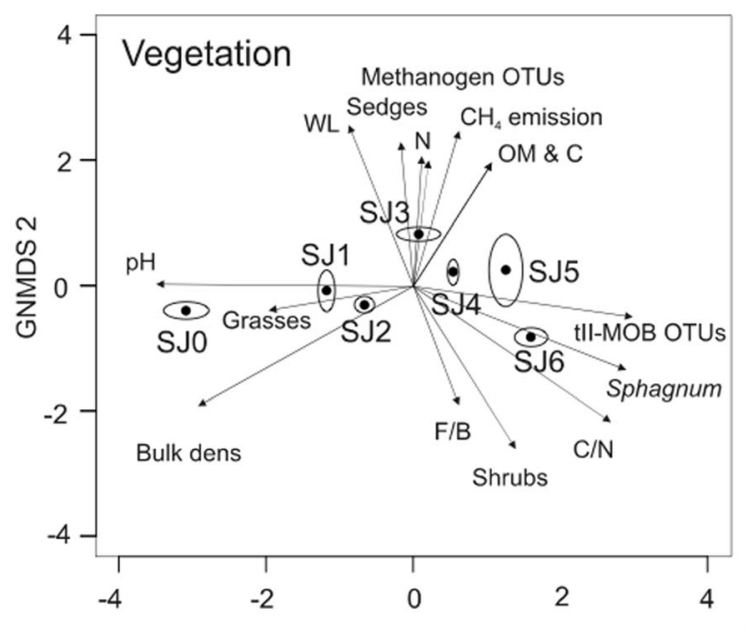

b.

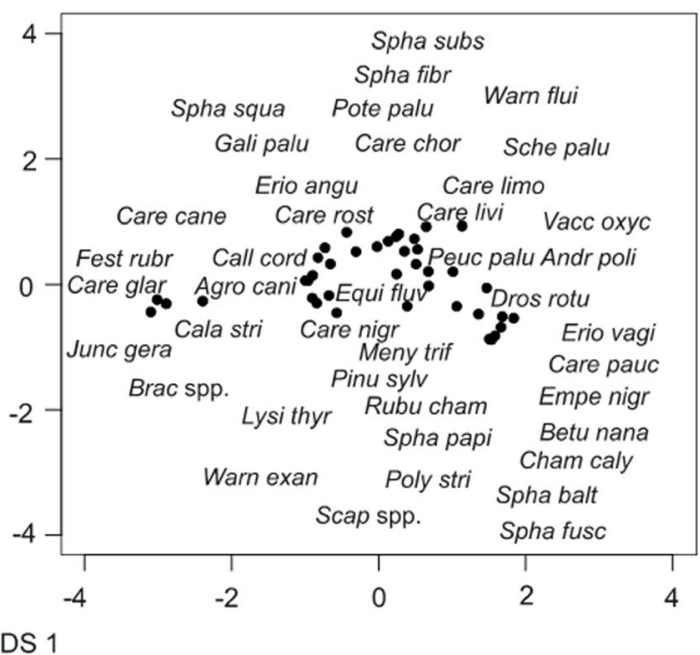

Figure 3. Global non-metric multidimensional scaling (GNMDS) ordination of a vegetation in sites SJ0-SJ6, and b plant species scores. Ovals represent $95 \%$ confidence intervals. The vectors in a represent environmental variables with correlation $\geq 0.5$. 
a.

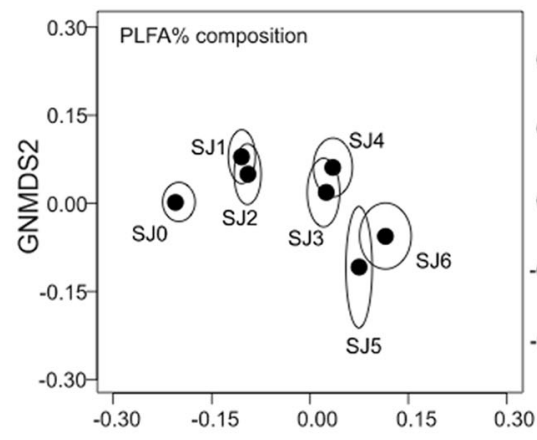

b.

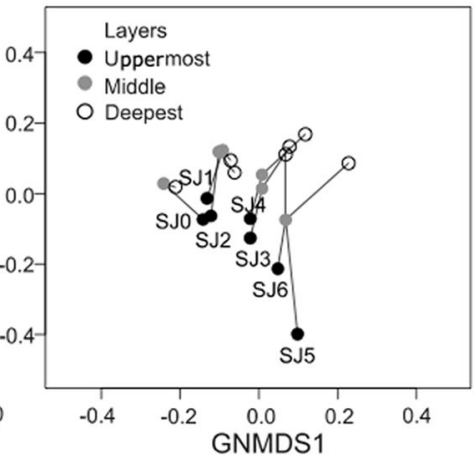

c.

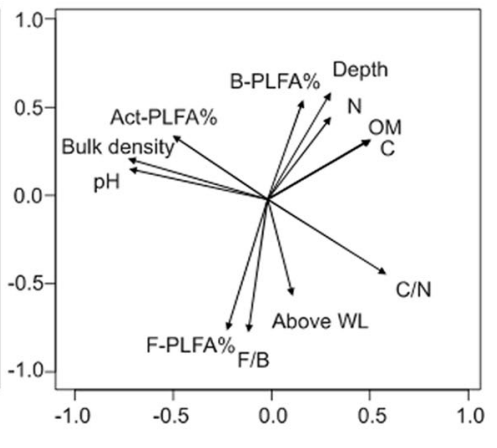

Figure 4. Global non-metric multidimensional scaling (GNMDS) ordination of phospholipid fatty acid (PLFA) results showing a sites SJ0-SJ6, b three peat layers with lines connecting the layers of each site, and correlations $\geq 0.5$ of environmental factors and PLFA summary variables with the ordination.

Table 2. Effect of Successional Stage and Peat Layer on Vegetation and Microbial Groups and Correlations of Community Compositions

\begin{tabular}{|c|c|c|c|c|c|c|}
\hline \multirow[t]{2}{*}{ Group } & \multicolumn{2}{|c|}{ PERMANOVA $^{\mathrm{b}} R^{2}$} & \multicolumn{4}{|l|}{ Procrustes $\mathbf{R}$} \\
\hline & Stage & Layer & Actinobacteria & Fungi & tII-MOB & Methanogens \\
\hline Vegetation & 0.53 & - & 0.33 & 0.64 & 0.52 & 0.54 \\
\hline Actinobacteria & 0.45 & 0.17 & - & - & - & - \\
\hline Fungi & 0.37 & 0.25 & 0.60 & - & - & - \\
\hline tII-MOB ${ }^{a}$ & 0.38 & 0.13 & 0.45 & 0.44 & - & - \\
\hline Methanogens & 0.55 & 0.12 & 0.58 & 0.54 & 0.40 & - \\
\hline
\end{tabular}

Phialocephala (SJ2), Venturia (SJ2, SJ4), Rhizocyphus (SJ5, SJ6), and Archaerhizomyces (SJ6) (Figure S4). Approximately $25 \%$ of the sequences clustered with Basidiomycota and the order Agaricales, but the genera varied with successional stage. The majority of actinobacterial 16S rRNA gene sequences clustered with Mycobacteriaceae (SJml-SJ6), Thermomonosporaceae (SJ0-SJ6), or Acidimicrobiaceae (SJml-SJ6) (Figure S5). All the tII-MOB pmoA sequences clustered with the alphaproteobacterial genus Methylocystis and showed strong similarity to sequences from peatlands (Figure S6). The most common methanogens along the gradient, based on morA clone sequences from sites SJml, SJ2, SJ3, and SJ5, were Methanobacteriaceae (SJ2, SJ5), Methanoflorentaceae (SJ3), Methanoregulaceae (SJm1, SJ2, SJ5), Methanosarcinaceae (SJm1, SJ5) Methanothrichaceae (SJm1, SJ2, SJ3), Methanomassiliicoccales (SJ3, SJ5), and Methanomicrobiaceae (SJml) (Figure S7).

\section{Discussion}

\section{Comparison of the Successional Patterns of Functional Groups}

In this study, we were interested to determine how the community changes of litter decomposers and $\mathrm{CH}_{4}$ cycling microbes are coupled along a peatland successional gradient, and how the changes relate to ecosystem processes in C cycling. This is the first study that integrates all these components along a peatland succession, which ranges from recently exposed shoreline to meadows, young fens, and finally bogs. The succession was evidenced as decreasing $\mathrm{pH}$, increasing $\mathrm{OM}$ accumulation and $\mathrm{C}: \mathrm{N}$, as seen in primary succession gradients (Pennanen and others 2001; Tscherko and others 2003), and as the increasing Sphagnum cover and peat thickness, characteristic of peatland succession (Korhola 1992; Hughes and Dumayne-Peaty 2002). Vegetation and the overall microbial community (based on PLFAs) changed gradually along the gradient. At the level of functional microbial 
a.

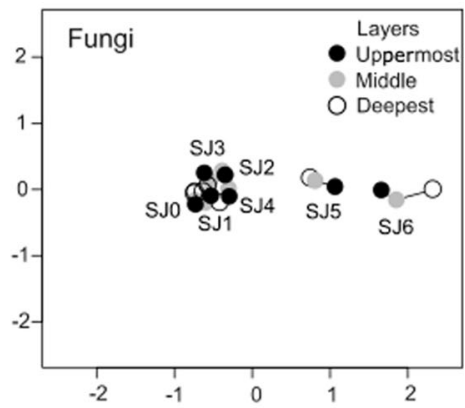

d.
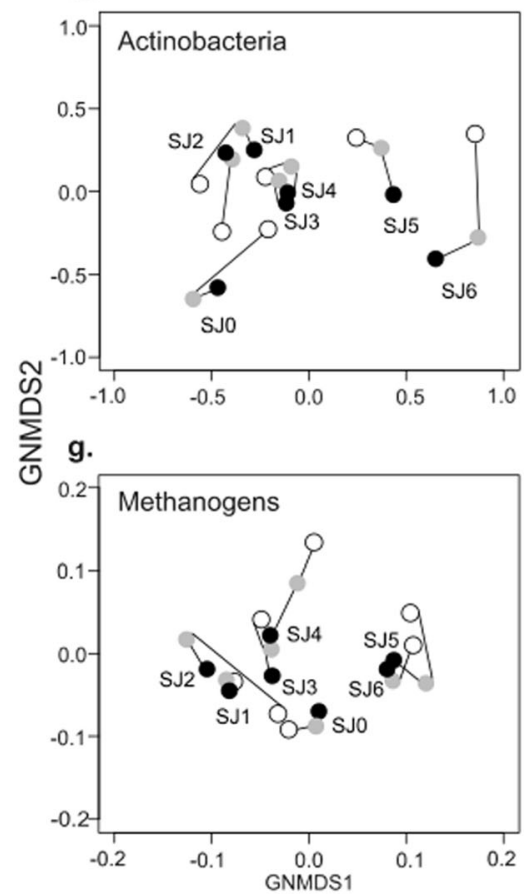

j.

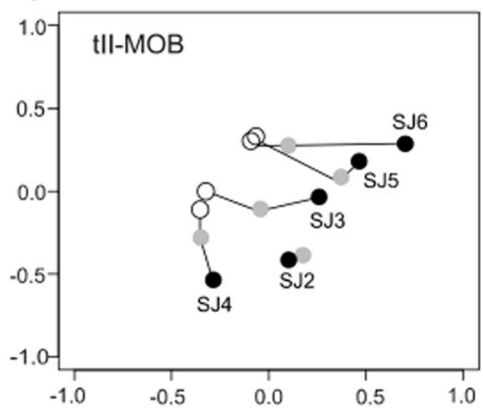

b.

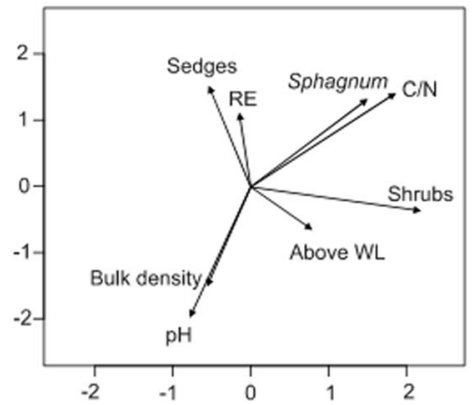

e.

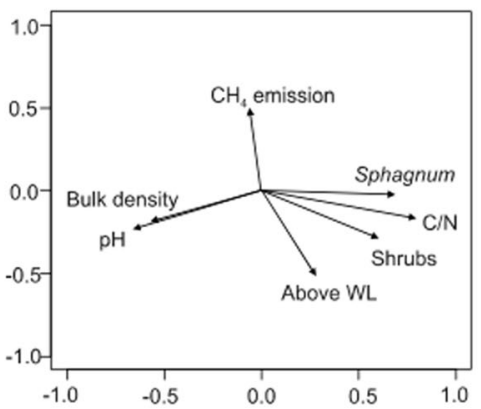

h.

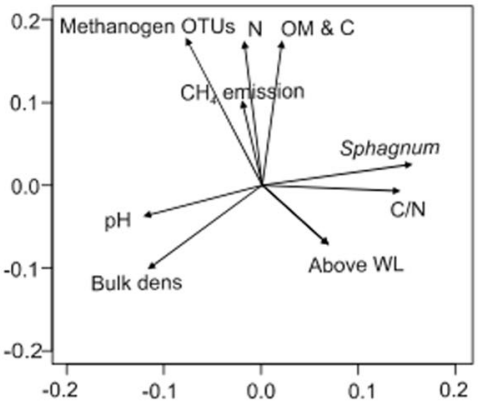

k.

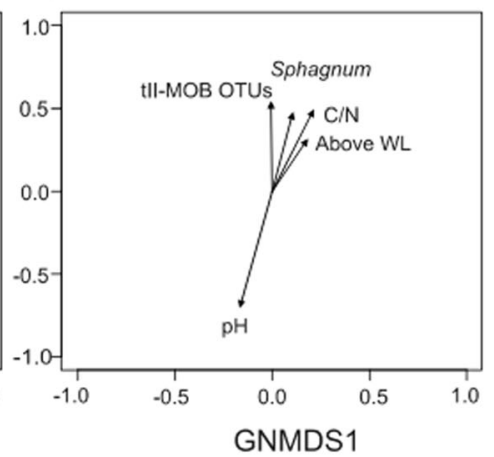

c.

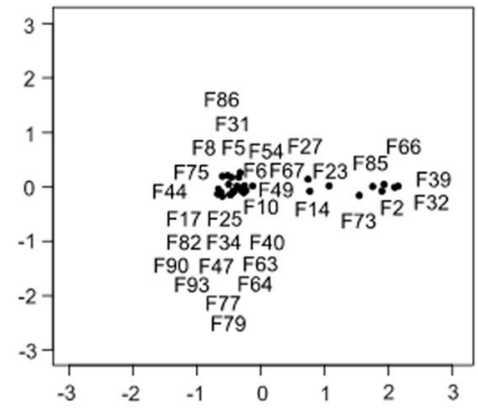

f.

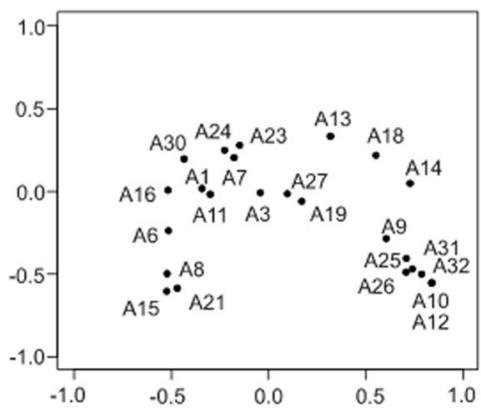

i.

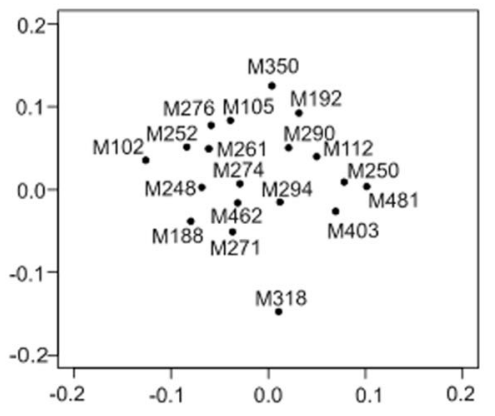

I.

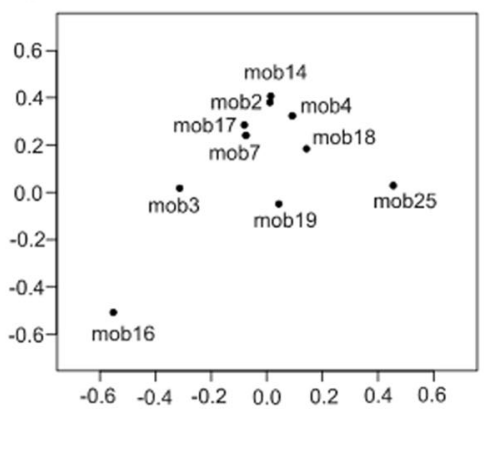

Figure 5. Global non-metric multidimensional scaling (GNMDS) ordination of communities and individual operational taxonomic units (OTUs) for fungi $(\mathbf{a}-\mathbf{c})$, actinobacteria $(\mathbf{d}-\mathbf{f})$, methanogens $(\mathbf{g}-\mathbf{i})$, and tII-MOB (j-l) in sites SJ0-SJ6. The vectors represent environmental variables with correlation $\geq 0.5$, except for ecosystem respiration $(\mathrm{RE})$, methane $\left(\mathrm{CH}_{4}\right)$ emissions, and distance to $\mathrm{WL} \geq 0.4$. Correlations of vectors are presented in Table S8 and layer-wise ordinations in Figure S3. 

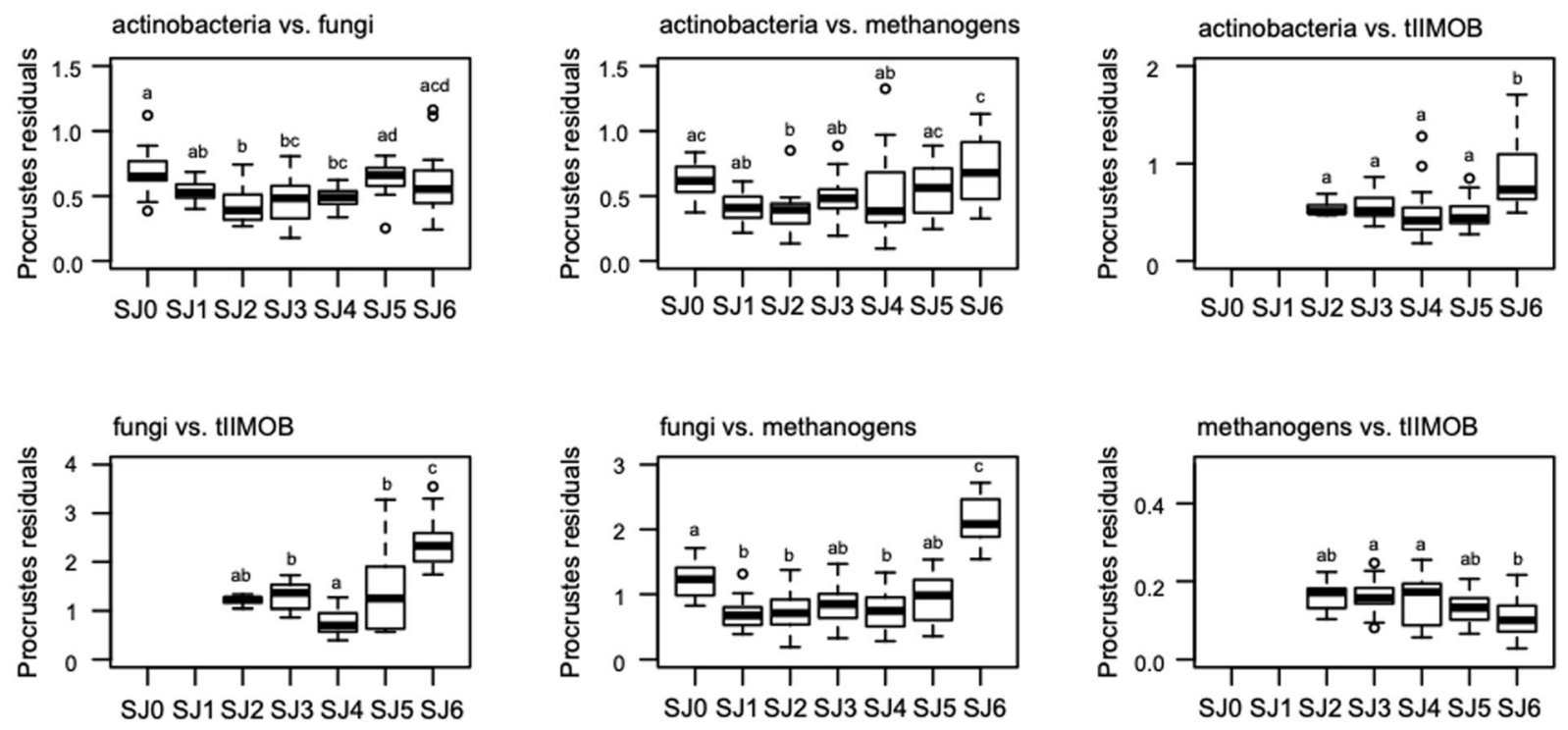

Figure 6. Strength of correlation of microbial functional groups determined as residuals of Procrustes analysis. tII-MOB denotes type II methanotrophs. A small residual value indicates stronger correlation. Different letters indicate significant differences between the successional stages at $p<0.05$. Ends of whiskers represent minimum and maximum values excluding outliers, which are shown as separate points.

groups, a common feature in the successional patterns of aerobic decomposers (fungi, actinobacteria), methanogens and, to some extent, methanotrophs was that the bog sites (SJ5, SJ6) showed distinct communities, rather than a gradual change. The oldest bog SJ6 also showed a decoupling of aerobic decomposer versus $\mathrm{CH}_{4}$-cycling communities, whereas the coupling between fungi versus actinobacteria, and tII-MOB versus methanogens was similar to the rest of the gradient. Bogs represent the climax stage of peatland succession where the low pH and abundant cover of Sphagnum with its chemical composition have an adverse effect on other organisms (van Breemen 1995) and constitute environmental filtering that is expected to structure the microbial communities (Medvedeff and others 2015; Ivanova and others 2020; Juottonen 2020; St. James and others 2021).

Against our expectation that actinobacterial and fungal communities (as plant litter degraders) would show greater correlation with vegetation composition than the $\mathrm{CH}_{4}$-cycling groups, only fungi followed this prediction. However, actinobacteria and fungi correlated strongly with each other, suggesting similar drivers along the gradient. The more pronounced drivers for both actinobacteria and fungi were acidity and Sphagnum moss cover, which were strongly interlinked (Laine and others 2021), and the cover of shrubs. Fungi form mycorrhizae with shrubs (Smith and Read 2008), and actinobacteria inhabit the shrub rhizosphere
(Aanderud and others 2008). Such associations may explain the particularly strong correlation observed here between these microbes and shrubs. Accordingly, ectomycorrhizal Lactarius and Russula (Basidiomycetes) were detected in bog SJ6 with the greatest shrub cover. Shrub cover and acidity may also explain the presence of Archaeorhizomycetes in bog SJ6, because these fungi are considered rootassociated fungi that favor high $\mathrm{C}$ content and acidity (Rosling and others 2013; Carrino-Kyker and others 2016). In another potentially aciditydriven pattern, actinobacterial Acidimicrobiaceae from the fen and bog sites were grouped with the acidophilic and potentially iron-cycling genera Acidimicrobium and Aciditerrimonas (Stackebrandt 2014), whereas those from the young sites with higher $\mathrm{pH}$ formed a separate cluster, suggesting different niche preferences related to peatland succession within Acidimicrobiaceae. Such preferences may explain why actinobacteria had similar drivers as fungi but did not follow the gradual vegetation change as consistently as fungi.

Methane-cycling microbes maintained a similar level of coupling along the gradient, but overall, the tII-MOB and methanogen communities did not correlate strongly and, indeed, were driven by different factors, none of which was WL. In previous studies, tII-MOB have followed methanogen communities, presumably because methanogens produce the substrate for MOB (Yrjälä and others 2011; Juottonen and others 2012). The lack of 
connection with methanogens in this peatland gradient with a wide range of habitats can be explained by the ability of many Methylocystis spp. to grow facultatively (without $\mathrm{CH}_{4}$ ) on acetate, ethanol, or hydrogen (Belova and others 2010; Im and others 2011; Hakobyan and others 2020). As expected, we found that Sphagnum cover was one of the best explanatory factors for tII-MOB community variation, because MOB inhabit the living Sphagnum mosses in addition to the decomposing peat (Kip and others 2010). The occurrence of MOB associated with living Sphagnum differed between the younger and older successional stages in this peatland succession gradient (Putkinen and others 2014). Type II MOB, which our approach targeted and which are the prevalent type of MOB in acidic northern peatlands (Chen and others 2008; Dedysh 2011; Zhou and others 2017), were detected in living Sphagnum throughout the gradient, whereas several type I MOB groups were prominent in the younger sites (Putkinen and others 2014). Such dominance of type I MOB could explain why we did not detect tII-MOB in the earliest seashore and meadow stages: SJml, SJ0, and SJl.

Methanogens showed the strongest response to the peatland successional gradient overall, consistent with the known separation of methanogen communities with peatland type and hydrology (Juottonen and others 2005; Cadillo-Quiroz and others 2006; Merilä and others 2006; Godin and others 2012). The strongest detected drivers of methanogen communities (that is, OM, C, and N content and Sphagnum cover) were tightly linked to the gradient. These findings suggest that methanogens are sensitive microbial indicators of peatland succession.

\section{Linking Microbial Community Changes with Ecosystem Functions Along the Peatland Gradient}

The greatest potential microbial activity (aerobic $\mathrm{CO}_{2}$ production and $\mathrm{CH}_{4}$ production and oxidation) and $\mathrm{RE}$ rates appeared in the early successional meadows and the youngest fen, although the community structures of the functional microbial groups in the meadows were not distinct from the other young peatland stages. This could be expected for actinobacteria and fungi as the widely distributed process of $\mathrm{CO}_{2}$ production cannot be attributed to specific microbial groups. Instead, the meadow stages exhibited the largest bacterial and fungal biomass, which points to a strong potential for microbial $\mathrm{C}$ turnover. In driving the strong microbial activity, the younger stages show greater levels of photosynthesis than the older stages (Leppälä and others 2008). The meadows had a greater cover of sedges, which suggests the availability of root exudates to fuel microbial processes, including methanogenesis (Ström and others 2003). Meadow SJ2 with strong $\mathrm{CH}_{4}$ production potential contained groups of methanogens associated with sedges or with elevated $\mathrm{CH}_{4}$ production activity levels: acetate-using Methanotrichaceae and hydrogenotrophic Methanobacteriaceae (Bräuer and others 2020).

It is surprising that all the microbial activity potentials peaked in the young meadow sites, given that our modeling results suggest that $\mathrm{CO}_{2}$ production, $\mathrm{CH}_{4}$ production, and $\mathrm{CH}_{4}$ oxidation potentials were driven by OM, acidity, and WL in very distinct ways. However, when the microbial biomass and $\mathrm{pH}$ (around 5) at these sites are considered, this was favorable for both $\mathrm{CH}_{4}$ production and oxidation. The meadows and the youngest fen represent dynamic environments that operate with considerable variations in resources and conditions, and do not possess as many limiting factors as the older peatlands with $\mathrm{pH}<5$. We propose that these early successional sites at the start of OM accumulation represent the 'Goldilocks' zone of peatland succession for $\mathrm{C}$ cycling: A sufficiently high and stable WL, but not too wet or too stable that allows both aerobic and anaerobic processes and the replenishment of redox-sensitive substrates; not too acidic; and adequate availability of $\mathrm{C}$ but not so much that processes would become $\mathrm{N}$ limited. This stage may act as a bottleneck for the development of a peatland with a thick peat layer and conditions that limit decomposition. Fen vegetation has been suggested as important for supporting multiple $\mathrm{C}$ cycling functions in peatlands (Robroek and others 2017) as the abundance of resources and processes makes these peatlands larger sources of $\mathrm{CO}_{2}$ and $\mathrm{CH}_{4}$ than the more stable older sites, and their dynamism makes these emissions sensitive to environmental changes.

\section{Role of Peat Layers and Microforms in Successional Patterns}

Strong depth-related variation and spatial variation complicate the comparison of peat profiles from widely differing peatlands, such as those in the gradient of this study. Successional changes in peat thickness, WL, the depth distribution of peat chemical composition, and the presence of microforms along the gradient must be considered in sampling design. First, our sampling scheme aimed 
to obtain good spatial coverage of the different microforms, which are known to affect microbial communities (Galand and others 2003; Deng and others 2013; Kotiaho and others 2013; Asemaninejad and others 2019). However, microformrelated variation was not evident at the community scale along the gradient (Figure S3). Second, we aimed to sample the peat above, around, and below the WL in each stage. Basing sampling depths solely on WL would have led to comparisons of microbial communities among very different peat substrates. It is possible that this sampling scheme, where the thickness of the sample layer increased with peat layer thickness, may have reduced the resolution for methanogens and tII-MOB, which are known to vary closer to the WL. Nonetheless, our sampling approach represents a carefully considered compromise designed to allow comparison of all stages along such an extensive peatland gradient.

\section{ConClusions}

Our study provides a comprehensive view on the interplay of peatland vegetation, decomposer communities, and $\mathrm{CH}_{4}$-cycling microbes in the regulation of $\mathrm{CO}_{2}$ and $\mathrm{CH}_{4}$ production, by addressing all these components in the same peatland successional gradient. The results highlight the role of young meadows and fens as dynamic sites sensitive to environmental changes (Leppälä and others $201 \mathrm{lb}$ ), with the greatest microbial potential for C release along the gradient. This major C turnover phase may represent a bottleneck in peatland succession that is necessary for peat accumulation. The dynamics of these young sites were not captured successfully by a peatland successional model (Tuittila and others 2013), which further underlines the need to understand the controls of $\mathrm{C}$ cycling in young peatlands with a thin peat layer. The concept of young peatland meadows as the 'Goldilocks' zone of carbon cycling could be applicable to other regions where sedge- or grass-dominated areas start accumulating peat, especially when thicker peat is accompanied by increasing acidity. The considerable potential for $\mathrm{C}$ turnover in the meadows was not apparent from microbial community composition alone, stressing the importance of measuring microbial activity and biomass. Because the microbial communities remained relatively similar throughout the meadow and older fen stages, climate or land use changes that increase vascular plant and sedge cover especially, could potentially turn such sites into similar hot spots of microbial C turnover as the young fens. On the other hand, microbial community compo- sition across the different functional groups was an excellent indicator of the strong restriction of $\mathrm{C}$ cycling activity in bogs. The uncoupling of decomposer and $\mathrm{CH}_{4}$-cycling communities further indicates the strong but distinct microbial response to Sphagnum dominance and increasing acidity and $\mathrm{C}: \mathrm{N}$ ratio. The specific microbial communities observed in bogs could be used as indicators of a peatland $\mathrm{C}$ sink and as a potential baseline of restoration measures that aim to stabilize the $C$ in the peat. As the response stems from the unique characteristics of Sphagnum peat, such indicators could be useful over a wide geographical range of Sphagnum-dominated peatlands.

\section{ACKNOWLEDGEMENTS}

We thank Hanna Aulanko, Juha Puranen, Sirpa Tiikkainen, Julie Rodriguez, and Gilberto DuranTorres for assistance in the laboratory, Sanna Ehonen, Meri Ruppel, Lauri Hirvisaari, and Markku Nikola for assistance with fieldwork, and Mirva Leppälä for assistance in sample processing. The work was funded by the Academy of Finland (Projects 131409, 218101, 315415, 287039, and 330840), funding from Kone Foundation to AML, and funding from the Finnish Society of Forest Science to MK.

\section{FUNDING}

Open access funding provided by University of Jyväskylä (JYU).

\section{Declarations}

Conflict of interest The authors declare that they have no conflict of interest.

\section{OPEN ACCESS}

This article is licensed under a Creative Commons Attribution 4.0 International License, which permits use, sharing, adaptation, distribution and reproduction in any medium or format, as long as you give appropriate credit to the original author(s) and the source, provide a link to the Creative Commons licence, and indicate if changes were made. The images or other third party material in this article are included in the article's Creative Commons licence, unless indicated otherwise in a credit line to the material. If material is not included in the article's Creative Commons licence and your intended use is not permitted by statutory regulation or exceeds the permitted use, you will 
need to obtain permission directly from the copyright holder. To view a copy of this licence, visit http://creativecommons.org/licenses/by/4.0/.

\section{REFERENCES}

Aanderud ZT, Shuldman MI, Drenovsky RE, Richards JH. 2008. Shrub-interspace dynamics alter relationships between microbial community composition and belowground ecosystem characteristics. Soil Biol Biochem 40:2206-2216.

Andersen R, Poulin M, Borcard D, Laiho R, Laine J, Vasander H, Tuittila ES. 2011. Environmental control and spatial structures in peatland vegetation. J Veg Sci 22:878-890.

Andersen R, Chapman SJ, Artz RRE. 2013. Microbial communities in natural and disturbed peatlands: a review. Soil Biol Biochem 57:979-994.

Anderson MJ. 2001. A new method for non-parametric multivariate analysis of variance. Austral Ecol 26:32-46.

Asemaninejad A, Thorn RG, Branfireun BA, Lindo Z. 2019. Vertical stratification of peatland microbial communities follows a gradient of functional types across hummock-hollow microtopographies. Écoscience 26:249-258.

Bauer IE, Gignac LD, Vitt DH. 2003. Development of a peatland complex in boreal western Canada: lateral site expansion and local variability in vegetation succession and long-term peat accumulation. Can J Bot 81:833-847.

Belova SE, Baani M, Suzina NE, Bodelier PLE, Liesack W, Dedysh SN. 2010. Acetate utilization as a survival strategy of peat-inhabiting Methylocystis spp. Environ Microbiol Rep 3:3646.

Bragazza L, Buttler A, Robroek BJ, Albrecht R, Zaccone C, Jassey VE, Signarbieux C. 2016. Persistent high temperature and low precipitation reduce peat carbon accumulation. Global Change Biol 22:4114-4123.

Bräuer S, Basiliko N, Siljanen HMP, Zinder S. 2020. Methanogenic archaea in peatlands. FEMS Microbiol Lett 367:fnaal72.

Breeuwer A, Robroek BJ, Limpens J, Heijmans MM, Schouten MG, Berendse F. 2009. Decreased summer water table depth affects peatland vegetation. Basic Appl Ecol 10:330-339.

Cadillo-Quiroz H, Bräuer S, Yashiro E, Sun C, Yavitt J, Zinder S. 2006. Vertical profiles of methanogenesis and methanogens in two contrasting acidic peatlands in central New York State, USA. Environ Microbiol 8:1428-1440.

Carrino-Kyker SR, Kluber LA, Petersen SM, Coyle KP, Hewins CR, DeForest JL, Smemo KA, Burke DJ. 2016. Mycorrhizal fungal communities respond to experimental elevation of soil $\mathrm{pH}$ and $\mathrm{P}$ availability in temperate hardwood forests. FEMS Microbiol Ecol 92:fiw024.

Chen Y, Dumont MG, Neufeld JD, Bodrossy L, Stralis-Pavese N, McNamara NP, Ostle N, Briones MJI, Murrell JC. 2008. Revealing the uncultivated majority: combining DNA stableisotope probing, multiple displacement amplification and metagenomic analyses of uncultivated Methylocystis in acidic peatlands. Environ Microbiol 10:2609-2622.

Dedysh SN. 2011 . Cultivating uncultured bacteria from northern wetlands: knowledge gained and remaining gaps. Front Microbiol 2:184.

Deng Y, Cui X, Lüke C, Dumont MG. 2013. Methanotrophs in Riganqiao peat. Environ Microbiol Rep 5:566-574.

Dieleman CM, Branfireun BA, McLaughlin JW, Lindo Z. 2015. Climate change drives a shift in peatland ecosystem plant community: implications for ecosystem function and stability. Global Change Biol 21:388-395.

Dieleman CM, Lindo Z, McLaughlin JW, Craig AE, Branfireun BA. 2016. Climate change effects on peatland decomposition and porewater dissolved organic carbon biogeochemistry. Biogeochemistry 128:385-396.

Frostegård Å, Bååth E. 1996. The use of phospholipid fatty acid analysis to estimate bacterial and fungal biomass in soil. Biol Fertil Soils 22:59-65.

Frostegård Å, Bååth E, Tunlid A. 1993. Shifts in the structure of soil microbial communities in limed forests as revealed by phospholipid fatty acid analysis. Soil Biol Biochem 25:723730.

Galand PE, Fritze H, Yrjälä K. 2003. Microsite-dependent changes in methanogenic populations in a boreal oligotrophic fen. Environ Microbiol 5:1133-1143.

Gardes M, Bruns TD. 1993. ITS primers with enhanced specificity for basidiomycetes-application to the identification of mycorrhizae and rusts. Mol Ecol 2:113-118.

Glaser PH, Hansen BC, Siegel DI, Reeve AS, Morin PJ. 2004. Rates, pathways and drivers for peatland development in the Hudson Bay Lowlands, northern Ontario, Canada. J Ecol 92:1036-1053.

Godin A, McLaughlin JW, Webster KL, Packalen M, Basiliko N. 2012. Methane and methanogen community dynamics across a boreal peatland nutrient gradient. Soil Biol Biochem 48:96105.

Gorham E. 1991. Northern peatlands, role in the carbon cycle and probable responses to climatic warming. Ecol Appl 1:182195.

Gunnarsson U, Malmer N, Rydin H. 2002. Dynamics or constancy in Sphagnum dominated mire ecosystems? A 40-year study. Ecography 25:685-704.

Hakobyan A, Zhu J, Glatter T, Paczia N, Liesack W. 2020. Hydrogen utilization by Methylocystis sp. strain SC2 expands the known metabolic versatility of type IIa methanotrophs. Metab Eng 61:181-196.

Harris LI, Roulet NT, Moore TM. 2020. Mechanisms for the development of microform patterns in peatlands of the Hudson Bay lowland. Ecosystems 23:741-767.

Helbig M, Waddington JM, Alekseychik P, Amiro BD, Aurela M, Barr AG, Chi J. 2020. Increasing contribution of peatlands to boreal evapotranspiration in a warming climate. Nat Clim Change 10:555-560.

Holmes AJ, Costello A, Lidstrom ME, Murrell JC. 1995. Evidence that particulate methane monooxygenase and ammonia monooxygenase may be evolutionarily related. FEMS Microbiol Lett 132:203-208.

Hughes PDM, Dumayne-Peaty L. 2002. Testing theories of mire development using multiple successions at Crymlyn Bog, West Glamorgan, South Wales, UK. J Ecol 90:456-471.

Im J, Lee SW, Yoon S, DiSpirito AA, Semrau JD. 2011. Characterization of a novel facultative Methylocystis species capable of growth on methane, acetate and ethanol. Environ Microbiol Rep 3:174-181.

Ivanova AA, Beletsky AV, Rakitin AL, Kadnikov VV, Philippov DA, Mardanov AV, Ravin NV, Dedysh SN. 2020. Closely located but totally distinct: highly contrasting prokaryotic diversity patterns in raised bogs and eutrophic fens. Microorganisms 8:484. 
Jaatinen K, Tuittila ES, Laine J, Yrjälä K, Fritze H. 2005. Methane-oxidizing bacteria in a Finnish raised mire complex: effects of site fertility and drainage. Microb Ecol 50:429-439.

Jaatinen K, Fritze H, Laine J, Laiho R. 2007. Effects of short-and long-term water-level drawdown on the populations and activity of aerobic decomposers in a boreal peatland. Global Change Biol 13:491-510.

Jassey VE, Chiapusio G, Binet P, Buttler A, Laggoun-Défarge F, Delarue F, Gilbert D. 2013. Above-and belowground linkages in Sphagnum peatland: climate warming affects plant-microbial interactions. Global Change Biol 19:811-823.

Jassey VE, Reczuga MK, Zielińska M, Słowińska S, Robroek BJ, Mariotte P, Bragazza L. 2018. Tipping point in plant-fungal interactions under severe drought causes abrupt rise in peatland ecosystem respiration. Global Change Biol 24:972-986.

Juottonen H. 2020. Disentangling the effects of methanogen community and environment on peatland greenhouse gas production by a reciprocal transplant experiment. Funct Ecol 34:1268-1279.

Juottonen H, Galand PE, Tuittila ES, Laine J, Fritze H, Yrjälä K. 2005. Methanogen communities and bacteria along an ecohydrological gradient in a northern raised bog complex. Environ Microbiol 7:1547-1557.

Juottonen H, Hynninen A, Nieminen M, Tuomivirta T, Tuittila E-S, Nousiainen H, Kell DK, Yrjälä K, Tervahauta A, Fritze H. 2012. Methane-cycling microbial communities and methane emission in natural and restored peatlands. Appl Environ Microbiol 78:6386-6389.

Kaiser C, Frank A, Wild B, Koranda M, Richter A. 2010. Negligible contribution from roots to soil-borne phospholipid fatty acid fungal biomarkers 18: $2 \omega 6,9$ and 18: $1 \omega 9$. Soil Biol Biochem 42:1650-1652.

Kip N, van Winden J, Pan Y, Bodrossy L, Reichart GJ, Smolders AJP, Jetten MSM, Damsté JSS, Op den Camp HJM. 2010. Global prevalence of methane oxidation by symbiotic bacteria in peat-moss ecosystems. Nat Geosci 3:617-621.

Korhola A. 1992. Mire induction, ecosystem dynamics and lateral extension on raised bogs in the southern coastal area of Finland. Fenn-Int J Geogr 170:25-94.

Kotiaho M, Fritze H, Merilä P, Tuomivirta T, Väliranta M, Korhola A, Karofeld E, Tuittila ES. 2013. Actinobacteria community structure in the peat profile of boreal bogs follows a variation in the microtopographical gradient similar to vegetation. Plant Soil 369:103-114.

Kroppenstedt RM. 1985. Fatty acids and menaquinone analysis of actinomycetes and related organisms. In: Goodfellow M, Minnikin DE, Eds. Chemical methods in bacterial systematics, . London: Academic Press. pp 173-199.

Laiho R. 2006. Decomposition in peatlands: reconciling seemingly contrasting results on the impacts of lowered water levels. Soil Biol Biochem 38:2011-2024.

Laine AM, Mehtätalo L, Tolvanen A, Frolking S, Tuittila E-S. 2019a. Combined effect of drainage, restoration and warming on boreal mire greenhouse gas fluxes. Sci Total Environ 647:169-181.

Laine AM, Mäkiranta P, Laiho R, Mehtätalo L, Penttilä T, Korrensalo A, Minkkinen K, Fritze H, Tuittila E-S. 2019 b. Warming impacts on boreal fen $\mathrm{CO}_{2}$ exchange under wet and dry conditions. Global Change Biol 25:1995-2008.

Laine AM, Lindholm T, Nilsson M, Kutznetsov O, Jassey VEJ, Tuittila ES. 2021. Functional diversity and trait composition of vascular plant and Sphagnum moss communities during peatland succession across land uplift regions. J Ecol 109:1774-1789.

Leppälä M, Kukko-Oja K, Laine J, Tuittila ES. 2008. Seasonal dynamics of $\mathrm{CO}_{2}$ exchange during primary succession of boreal mires as controlled by phenology of plants. Ecoscience 15:460-471.

Leppälä M, Laine AM, Seväkivi ML, Tuittila ES. 201la. Differences in $\mathrm{CO}_{2}$ dynamics between successional mire plant communities during wet and dry summers. J Veg Sci 22:357366.

Leppälä M, Oksanen J, Tuittila ES. 2011b. Methane flux dynamics during mire succession. Oecologia 165:489-499.

Lisboa FJG, Peres-Neto PR, Chaer GM, Jesus EdC, Mitchell RJ, Chapman SJ, Berbera RLL. 2014. Much beyond Mantel: bringing Procrustes association metric to the plant and soil ecologist's toolbox. PLoS ONE 9:e101238.

Luton PE, Wayne JM, Sharp RJ, Riley PW. 2002. The $m c r A$ gene as an alternative to $16 \mathrm{~S}$ rRNA in the phylogenetic analysis of methanogen populations in landfill. Microbiology 148:35213530 .

Mäkiranta P, Laiho R, Mehtätalo L, Strakova P, Sormunen J, Minkkinen K, Penttilä T, Fritze H, Tuittila E-S. 2018. Responses of phenology and biomass production of boreal fens to climate warming under different water-table level regimes. Global Change Biol 24:944-956.

Medvedeff CA, Bridgham SD, Pfeifer-Meister L, Keller JK. 2015. Can Sphagnum leachate chemistry explain differences in anaerobic decomposition in peatlands? Soil Biol Biochem 86:34-41.

Merilä P, Galand PE, Fritze H, Tuittila ES, Kukko-oja K, Laine J, Yrjälä K. 2006. Methanogen communities along a primary succession transect of mire ecosystems. FEMS Microbiol Ecol 55:221-229.

Monier E, Sokolov A, Schlosser A, Scott J, Gao X. 2013. Probabilistic projections of 21 st century climate change over Northern Eurasia. Environ Res Lett 8:045008.

Oksanen J, Blanchet FG, Kindt R, Legendre P, Minchin PR, OHara RB, Simpson GL, Solymos P, Henry M, Stevens H, Wagner. 2015. vegan: Community Ecology Package R package version 2.3-0. https://CRAN.R-project.org/package=vegan.

Peltoniemi K, Fritze H, Laiho R. 2009. Response of fungal and actinobacterial communities to water-level drawdown in boreal peatland sites. Soil Biol Biochem 41:1902-1914.

Peltoniemi K, Straková P, Fritze H, Alvira Iráizoz P, Pennanen T, Laiho R. 2012. How water-level drawdown modifies litterdecomposing fungal and actinobacterial communities in boreal peatlands. Soil Biol Biochem 51:20-34.

Peltoniemi K, Laiho R, Juottonen $\mathrm{H}$, Kiikkilä $\mathrm{O}$, Mäkiranta $\mathrm{P}$, Minkkinen K, Pennanen T, Penttilä T, Sarjala T, Tuittila ES, Tuomivirta TT, Fritze H. 2015. Microbial ecology in a future climate: effects of temperature and moisture on microbial communities of two boreal fens. FEMS Microbiol Ecol 91:fiv062.

Peltoniemi K, Laiho R, Juottonen H, Bodrossy L, Kell DK, Minkkinen K, Mäkiranta P, Mehtätalo L, Siljanen HMP, Tuittila ES, Tuomivirta TT, Fritze H. 2016. Responses of methanogenic and methanotrophic communities to warming in varying moisture regimes of two boreal fens. Soil Biol Biochem 97:144-156.

Pennanen T, Strömmer R, Markkola A, Fritze H. 2001. Microbial and plant community structure across a primary succession gradient. Scand J for Res 16:37-43. 
Peres-Neto PR, Jackson DA. 2001. How well do multivariate data sets match? The advantages of a Procrustean superimposition approach over the Mantel test. Oecologia 129:169-178.

Perkiomäki J, Fritze H. 2002. Short and long-term effects of wood ash on the boreal forest humus microbial community. Soil Biol Biochem 34:1343-1353.

Putkinen A, Larmola T, Tuomivirta T, Siljanen HMP, Bodrossy L, Tuittila ES, Fritze H. 2014. Peatland succession induces a shift in the community composition of Sphagnum-associated active methanotrophs. FEMS Microbiol Ecol 88:596-611.

R Core Team. 2014. R: a language and environment for statistical computing. Vienna: R Foundation for Statistical Computing.

Riutta T, Laine J, Tuittila ES. 2007. Sensitivity of $\mathrm{CO}_{2}$ exchange of fen ecosystem components to water level variation. Ecosystems 10:718-733.

Robroek BJ, Jassey VE, Kox MA, Berendsen RL, Mills RT, Cécillon L, Puissant J, Meima-Franke M, Bakker PAHM, Bodelier PL. 2015. Peatland vascular plant functional types affect methane dynamics by altering microbial community structure. J Ecol 103:925-934.

Robroek BJ, Jassey VE, Beltman B, Hefting MM. 2017. Diverse fen plant communities enhance carbon-related multifunctionality, but do not mitigate negative effects of drought. $\mathrm{R}$ Soc Open Sci 4:170449.

Rosling A, Timling I, Taylor DL. 2013. Archaeorhizomycetes: patterns of distribution and abundance in soil. In: Horwitz B, Mukherjee P, Mukherjee M, Kubicek C, Eds. Genomics of soil-and plant-associated fungi, . Berlin: Springer. pp 333-349.

Roulet N, Moore T, Bubier J, Lafleur P. 1992. Northern fens: methane flux and climatic change. Tellus B 44:100-105.

Smith SE, Read DJ. 2008. Mycorrhizal symbiosis, 3rd edn. Cambridge: Academic Press. p 800.

Sottocornola M, Laine A, Kiely G, Byrne KA, Tuittila ES. 2009. Vegetation and environmental variation in an Atlantic blanket bog in south-western Ireland. Plant Ecol 203:69-81.

St James AR, Yavitt JB, Zinder SH, Richardson RE. 2021. Linking microbial Sphagnum degradation and acetate mineralization in acidic peat bogs: from global insights to a genome-centric case study. ISME J 15:293-303.

Stach JE, Maldonado LA, Ward AC, Goodfellow M, Bull AT. 2003. New primers for the class actinobacteria: application to marine and terrestrial environments. Environ Microbiol $5: 828-841$.

Stackebrandt E. 2014. The family Acidimicrobiaceae. In: Rosenberg E, DeLong EF, Lory S, Stackebrandt E, Thompson F, Eds. The prokaryotes, . Berlin: Springer. pp 5-12.

Straková P, Penttilä T, Laine J, Laiho R. 2012. Disentangling direct and indirect effects of water table drawdown on above- and belowground plant litter decomposition: consequences for accumulation of organic matter in boreal peatlands. Global Change Biol 18:322-335.

Ström L, Ekberg A, Mastepanov M, Christensen TR. 2003. The effect of vascular plants on carbon turnover and methane emissions from a tundra wetland. Global Change Biol 9:11851192.

Tahvanainen T. 2011. Abrupt ombrotrophication of a boreal aapa mire triggered by hydrological disturbance in the catchment. J Ecol 99:404-415.

Tscherko D, Rustemeier J, Richter A, Wanek W, Kandeler E. 2003. Functional diversity of the soil microflora in primary succession across two glacier forelands in the Central Alps. Eur J Soil Sci 54:685-696.

Tuittila ES, Juutinen S, Frolking S, Väliranta M, Laine AM, Miettinen A, Merilä P. 2013. Wetland chronosequence as a model of peatland development: Vegetation succession, peat and carbon accumulation. Holocene 23:25-35.

Tuomivirta TT, Yrjälä K, Fritze H. 2009. Quantitative PCR of pmoA using a novel reverse primer correlates with potential methane oxidation in Finnish fen. Res Microbiol 160:751756.

Urbanová Z, Bárta J. 2016. Effects of long-term drainage on microbial community composition vary between peatland types. Soil Biol Biochem 92:16-26.

Urbanová Z, Picek T, Bárta J. 2011. Effect of peat re-wetting on carbon and nutrient fluxes, greenhouse gas production and diversity of methanogenic archaeal community. Ecol Eng 37:1017-1026.

van Breemen N. 1995. How Sphagnum bogs down other plants. Trends Ecol Evolut 10:270-275.

Weltzin JF, Pastor J, Harth C, Bridgham SD, Updegraff K, Chapin CT. 2000. Response of bog and fen plant communities to warming and water-table manipulations. Ecology 81:34643478

Wood SN. 2006. Generalized additive models: an introduction with R. Boca Raton: Chapman and Hall/CRC

Yrjälä $\mathrm{K}$, Tuomivirta $\mathrm{T}$, Juottonen $\mathrm{H}$, Putkinen A, Lappi $\mathrm{K}$, Tuittila ES, Penttilä T, Laine J, Peltoniemi K, Fritze H. 2011 $\mathrm{CH}_{4}$ production and oxidation processes in a boreal fen ecosystem after long-term water table drawdown. Global Change Biol 17:1311-1320.

Yu ZC. 2012. Northern peatland carbon stocks and dynamics: a review. Biogeosciences 9:4071-4085.

Zhou X, Zhang Z, Tian L, Xiujun Li, Tian C. 2017. Microbial communities in peatlands along a chronosequence on the Sanjiang Plain, China. Sci Rep 7:9567. 